\title{
Columbanus's De mundi transitu in Early Medieval England: A New Source for an Old English Homily (Irvine VII) in Oxford, Bodleian Library, Bodley 343
}

\author{
Thijs Porck
}

\begin{abstract}
Ardor refriescit, nitor quualescit, Amor abolescit, lux obtenebrescit. hat acolað, hwit asolað, leof alapað, leoht apeostrað. Senescunt quę eterna non sunt. æghwæt ealdað pæs pe ece ne byð. ${ }^{1}$
\end{abstract}

These Latin-Old English proverbs, added to the Royal Psalter by an eleventhcentury hand, express a theme that is central to many Old English poems and homilies: transience. ${ }^{2}$ To express the fleeting nature of the world, poets and homilists had a large repertoire of motifs at their disposal. ${ }^{3}$ In addition to the well-known and frequently discussed ubi sunt passages, ${ }^{4}$ these motifs included ruined cities, ${ }^{5}$ exhortations of the dead to the living, ${ }^{6}$ and the

1 London, BL, Royal 2. B. v, fol. 6r. "What is hot grows cool, what is white becomes dirty, what is dear becomes hateful, what is light becomes dark. Everything which is not eternal grows old." The Old English does not completely match the sense of the Latin; e.g., Latin "amor abolescit" (love will wane) and Old English "leof alapað” (what is dear becomes hateful). Unless otherwise noted, all translations are my own.

2 Christine Fell, "Perceptions of Transience," in Cambridge Companion to Old English Literature, ed. Malcolm Godden and Michael Lapidge, 2nd ed., Cambridge Companions to Literature (Cambridge, 2013), 180-97.

3 See, e.g., Hildegard L. C. Tristram, “The Early Insular Elegies: ITEM ALIA," in Celtic Linguistics, ed. Martin J. Ball, James Fife, Erich Poppe and Jenny Rowland (Amsterdam, 199o), pp. 348-49.

4 J. E. Cross, “'Ubi sunt' Passages in Old English-Sources and Relationships," VetenskapsSocietetens $i$ Lund Årsbok (1956), 25-44; L. R. McCord, "A Probable Source for the ubi sunt Passage in Blickling Homily V," NM 82 (1981), 36o-61; Claudia Di Sciacca, "The ubi sunt Motif and the Soul-and-Body Legend in Old English Homilies: Sources and Relationships," JEGP 105 (2006), 365-87.

5 K. Hume, "The 'Ruin Motif' in Old English Poetry," Anglia 94 (1976), 339-6o.

6 J. E. Cross, “The Dry Bones Speak-A Theme in Some Old English Homilies," JEGP 56 (1957), 434-39.

(C) THIJS PORCK, 2021 | DOI:10.1163/9789004439283_010

This is an open access chapter distributed under the terms of the CC BY 4.0 license. 
elderly body in decline. ${ }^{7}$ Sources and analogues for these elegiac motifs have been traced in various traditions, ranging from Germanic oral tradition to early Christian Latin poetry, patristic writing and Old Welsh poetic lamentations. ${ }^{8}$

A text that has often been associated with the Old English elegies, in particular, is the Hiberno-Latin poem De mundi transitu by the Irish missionary Columbanus of Bobbio (d. 616). Ida Gordon, for instance, linked Columbanus's poem to The Seafarer, arguing that the two poems have a number of ideas concerning transience in common, including the daily passing of this world and the brevity of earthly possessions. ${ }^{9} \mathrm{R}$. F. Leslie stresses a close connection between De mundi transitu and The Wanderer, noting the similarity between Columbanus's opening lines and lines $62 \mathrm{~b}-63$ of the Old English poem: ${ }^{10}$

Mundus iste transibit

Cottidie decrescit ${ }^{11}$

$\begin{array}{ll}\text { Swa pes middangeard } \\ \text { ealra dogra gehwam } & \text { dreoseð ond feallep. }{ }^{12}\end{array}$

Leslie's identification of Columbanus as "the one who is most akin to the Old English poets of The Wanderer and The Seafarer" prompted Michael Allen and Daniel Calder to include De mundi transitu in their foundational collection of sources and analogues of Old English poetry. ${ }^{13}$ Since then, however, the connection between this Hiberno-Latin poem and the Old English elegiac corpus has not received much attention. ${ }^{14}$ In fact, scholars have so far

$7 \quad$ Thijs Porck, Old Age in Early Medieval England: A Cultural History, Anglo-Saxon Studies 33 (Woodbridge, Suffolk, 2019), pp. 81-104.

8 See, e.g., the overview in Anne L. Klinck, The Old English Elegies: A Critical Edition and Genre Study (Montreal \& Kingston, 1992), pp. 230-43.

$9 \quad$ The Seafarer, ed. I. L. Gordon, Methuen's Old English Library (London, 196o), pp. 22-23.

10 The Wanderer, ed. R. F. Leslie (Manchester, 1966), p. 29.

11 Columbanus, De mundi transitu, ed. and trans. G. S. M. Walker, Sancti Columbani Opera (Dublin, 1957), lines 1-2. "This world shall pass, daily it declines." All subsequent quotations and translations are taken from this edition. In a few places, I have made slight adjustments to Walker's translation; these are put between square brackets.

12 The Wanderer, ed. Klinck, Old English Elegies, lines 62b-63. "Thus this world declines and falls each and every day."

13 The Wanderer, ed. Leslie, p. 29; Sources and Analogues of Old English Poetry: The Major Latin Texts in Translation, trans. Michael J. B. Allen and Daniel G. Calder (Cambridge, 1976), pp. $135^{-36 .}$

14 E.g., Columbanus is not mentioned in the overview of sources and analogues in Klinck, Old English Elegies, pp. 230-43. 
been unable to establish whether Columbanus's poem actually circulated in early medieval England. ${ }^{15}$

This paper, for the first time, calls attention to an Old English paraphrase of over sixty lines of Columbanus's De mundi transitu in the anonymous Old English composite homily Irvine VII in Oxford, Bodleian Library, Bodley 343. The discovery of this source reveals a number of scribal corruptions in the extant versions of both texts and demonstrates that Columbanus's poem was indeed known in early medieval England. Below, the homily in question is first introduced, followed by a description of De mundi transitu. In the last part of the paper, the two relevant passages of the two texts are analysed.

\section{Irvine Homily VII in Bodley 343}

Oxford, Bodleian Library, Bodley 343 is a mid-twelfth-century manuscript, containing a large collection of homilies and homiletic pieces in Latin and Old English. ${ }^{16}$ The greater majority of the Latin portion of the manuscript has recently been identified as the Carolingian Homiliary of Angers, ${ }^{17}$ while most of the manuscript's Old English items are works by Ælfric. Bodley 343 also features nine anonymous homilies, of which three are unique to this manuscript. While the language of the manuscript has been updated to the transitional English of the mid-twelfth century, these unique anonymous items are considered to date to the late tenth century. ${ }^{18}$

15 The Fontes database, for instance, does not list Columbanus among its source authors. Similarly, no extant manuscripts of Columbanus's works were owned or written in England before $1100 \mathrm{AD}$, see Gneuss/Lapidge. Nevertheless, his work was not completely unknown in early medieval England, since a number of his sermons were cited by the eighth-century anchorite Alchfrid in a letter; see F. M. Biggs, "A Further Quotation of Columbanus in Alchfrid's Letter to Hyglac," $N \& Q$ n.s. 53 (2006), $12-14$.

16 For descriptions of this manuscript, see Ker, Catalogue, no. 310; Irvine, xviii-liv; Jonathan Wilcox, "Oxford, Bodleian Library, Bodley 343 (2406): Ælfric, 'Catholic Homilies,' other Homilies," in Homilies by Elfric and Other Homilies, ASM 17 F 17 Tempe, 2008), pp. 71-101; Aidan Conti \& Orietta Da Rold, "Oxford, Bodleian Library, Bodley 343 (2406)," in The Production and Use of English Manuscripts 1060 to 1220, ed. Orietta Da Rold, Takako Kato, Mary Swan and Elaine Treharne (Leicester, 2010). Available at https://emio6o.stanford .edu/oxford-bodleian-library-bodley-343-2406. Accessed 2018 August 31.

17 Aidan Conti, "The Circulation of the Old English Homily in the Twelfth Century: New Evidence from Oxford, Bodleian Library, MS Bodley 343," in The Old English Homily: Precedent, Practice, and Appropriation, ed. Aaron J. Kleist, Studies in the Early Middle Ages 17 (Turnhout, 2007), pp. 365-402.

18 E.g., D. G. Scragg, "The Corpus of Vernacular Homilies and Prose Saints' Lives before Elfric," in Old English Prose: Basic Readings, ed. P. E. Szarmach, Basic Readings in Anglo-Saxon England 5 (New York \& London, 200o), pp. 93-94. 
The last of these three unique anonymous homilies is central to this paper. This composite homily has been edited twice, as Belfour XII "A Message from the Tomb" in 1909 and as Irvine VII "The Transience of Earthly Delights" in $1993 .{ }^{19}$ Donald Scragg and Susan Irvine both describe the homily as consisting of two separate parts. ${ }^{20}$ The first part (lines 1-93) ends with a typical concluding formula: "and heo mid him and mid his halzan libbæb, and rixæð a on eccenesse" (lines 92-93; and they will live with him and with his saints, and rule forever in eternity). This closing formula in the middle of Irvine viI makes the homily come across as disjointed. Indeed, as Irvine notes, "[ $t$ ]he compiler has apparently yoked together two extracts from already existing homilies without even attempting to create any logical link between them." ${ }^{21}$ The second part of the homily (lines 94-167) derives from an anonymous homily known as Vercelli $\mathrm{x}$, versions of which are preserved in various other, earlier manuscripts. Be that as it may, the part of Irvine VII that overlaps with Vercelli $\mathrm{X}$ is independent from other extant versions of this homily and, despite the later date of its manuscript, it could ultimately stem from an exemplar closer to its original. ${ }^{22}$

The first part of Irvine VII also derives from an earlier English composition. This is confirmed by Hans Schabram's analysis of the homily's vocabulary. Primarily interested in the homily's use of words for pride, Schabram calls attention to the occurrence of the tautological pairings "on oferhydo [...] on ofermetto" (lines 11-12) and "pa modizæn 7 pa oferhudizen" (lines 71-72). The original must have had words related to the Anglian word oferhygd (pride) and later West Saxon scribal influence prompted the introduction of the West Saxon alternatives based on oE $m \bar{o} d$. Schabram also calls attention to other Anglian traces, including the use of oE gewinn in the sense of "labour" (lines 85 and 9o) and the Anglian form "morber" (line 88; murder) rather than West Saxon morp. ${ }^{23}$ As such, Schabram holds that Irvine viI stems from an earlier Anglian original, which was copied by a West Saxon scribe, before it was entered into Bodley 343.

James Cross accurately described Irvine VII as "a patchwork of borrowings stressing the transitoriness of earthly things and the need to prepare for death

19 Belfour, pp. 124-35; Irvine, pp. 197-202. All quotations from Irvine VII are taken from Irvine's edition.

20 Scragg, "The Corpus of Vernacular Homilies," p. 94; Irvine, p. 181.

21 Ibid., p. 181.

$22 \quad V H, \mathrm{p} .193$.

23 Hans Schabram, Superbia. Studien zum altenglischen Wortschatz. Teil I: Die dialektale und zeitliche Verbreitung des Wortguts (Munich, 1965), pp. 83-84. 
and the Last Judgement." ${ }^{24}$ On the basis of its contents and sources, Irvine viI may be divided into four sections:

(a) lines 1-21: An exhortation of the dead to the living, adapted from Caesarius of Arles' sermon De Elemosinis. ${ }^{25}$

(b) lines 22-65: A description of Doomsday, for which no source has been identified.

(c) lines 65-93: A reflection on the transience of earthly delights, based on Columbanus's De munditransitu (discussed below). This section ends with a typical closing formula.

(d) lines 94-167: An appeal to thank God for His benefits, a discussion of transience with ubi sunt passages, and another exhortation to thank God and live piously, all derived from Vercelli x. ${ }^{26}$

Section (a) paves the way for the themes dealt with in sections (b) and (c). The audience is first asked to consider the transience of wealth and pride whenever they look upon the graves of rich people. If the deceased were able to speak, the homilist holds, they would remind anyone that death is inevitable: "Iu ic wæs swylc pu nu eart, and 3yt pu iwurðæst swulc ic nu eom'" (lines 14-15; I used to be like you are now, and yet you will become as I am now). Following this memento mori, the homilist launches into a description of Doomsday. Having outlined the fates of the righteous and the damned, the homilist concludes:

Penne is us mucel neod, leofe men, pæt we Godes bodu zeorne healden and earniæn pæt we moten mid heofenwaræ lifes brucen, and pæt we ne weorpæn aweorpen on pa deopestæ helles grunde. ${ }^{27}$

In section (c), the homilist returns to the initial themes of mortality and transience. First, the inevitability of death is repeated, along with a contrast between secular wealth, which is temporary, and punishment in the afterlife, which is eternal. Next, the human body is compared to withering plants so as to suggest

24 Cross, "The Dry Bones Speak," p. 436.

25 The use of this source is discussed in Cross, "The Dry Bones Speak," pp. 434-39, and Hilary Fox, "The Talking Dead: Exhortations of the Dead to the Living in Anglo-Saxon Writing," in Dealing with the Dead: Mortality and Community in Medieval and Early Modern Europe, ed. Thea Tomaini, Explorations in Medieval Culture 5 (Leiden, 2018), pp. 17-24.

26 Irvine, pp. 179-81, 192-96; VH, pp. 191-95.

27 Lines 63-65. "There is a great need, then, dear people, that we eagerly observe God's commandments and earn that we are allowed to enjoy life with those who live in heaven, and that we are not thrown into the deepest pit of hell." 
that, rather than loving one's fragile youth, one should be devoted to Christ's countenance and strive to earn a place in heaven. Section (c) ends with a description of the joys of heaven, possibly marking the end of the text in a previous version, before it was prefixed to the passage from Vercelli $\mathrm{x}$.

Although no occasion for Irvine VII is specified in Bodley 343, this homily has been associated with Rogationtide, given its themes of death, transience and Doomsday. ${ }^{28}$ The opening lines of the homily, which entreat the audience to consider the transience of wealth as they pass by the tombs of rich men, also fit well with a Rogationtide homily. During these gangdagas (walking days) preceding Ascension Thursday, the community would make daily boundary walks, during which many a tomb would have been encountered. ${ }^{29}$

\section{Columbanus's De mundi transitu}

The Irish monk and scholar Columbanus (d. 616) is an important figure in the history of early Christianity in Ireland and the Continent. After having spent most of his life in Bangor Abbey, he travelled to the continent as a missionary. He founded various monasteries in Francia and Italy, most notably the abbey of Bobbio in present-day Italy. In addition to a set of monastic rules and a penitential, Columbanus also wrote a number of sermons (the Instructiones) and letters. While still in Ireland, Columbanus had also composed "many other works suitable for singing," according to his biographer Jonas of Bobbio. ${ }^{30}$ While various poems have been attributed to Columbanus, the authenticity of this poetic corpus has been a matter of debate. However, a strong case has been made for his authorship of De mundi transitu. ${ }^{31}$

Dieter Schaller has established the authorship of Columbanus for De mundi transitu on the basis of correspondences in thought and phrasing with some of the Irish missionary's Instructiones. ${ }^{32}$ In addition, David Howlett has shown

28 Irvine, p. 181.

29 Cf. Bazire-Cross, pp. xxii-xxiv.

30 Jonas of Bobbio, Life of Columbanus, trans. A. O'Hara and Ian Wood, Translated Texts for Historians 64 (Liverpool, 2017), 1.3, p. 102.

31 The debate concerning Columbanus's poetic oeuvre is outlined in Michael Lapidge, "Epilogue: Did Columbanus Compose Metrical Verse?," in Columbanus: Studies on the Latin Writings, ed. Michael Lapidge (Woodbridge, Suffolk, 1997), pp. 274-85. For De mundi transitu specifically, see Dieter Schaller, "De mundi transitu: A Rhythmical Poem by Columbanus?," in Columbanus, ed. Lapidge, pp. 240-54. Cf. J. W. Smit, Studies on the Language and Style of Columba the Younger (Columbanus) (Amsterdam, 1971), p. 222, who rejects Columbanus as the author of this poem.

Schaller, "De mundi transitu," pp. 252-54. 
that the greater majority of the vocabulary of De mundi transitu recurs elsewhere in the prose texts ascribed to Columbanus. Howlett also points out that lines $25^{-26}$ form an anagram of "Columba loquitur clanculo ridet benguirr" (Columba speaks secretly, Bangor smiles), which suggests the poem was written before Columbanus left Bangor for the Continent around the year $590 \mathrm{AD} .{ }^{33}$ An early modern annotation in the only extant manuscript that features the full text of De munditransitualso attributes the poem to Columbanus. ${ }^{34}$

Columbanus's De munditransitu is a short but highly wrought poem, written in a style that is typical for Hiberno-Latin poets of the early Middle Ages. ${ }^{35} \mathrm{It}$ consists of 120 heptasyllabic lines, divided into thirty stanzas of four lines each. In addition to rhyme, which occasionally extends to three syllables, the poem also features alliteration. Furthermore, Howlett has shown that Columbanus used various rhyme schemes, chiasmus, and the golden section to structure his poem. Howlett further calls attention to the work's calendrical features: seven syllables for every day in the week; four lines per stanza for every week in a month; thirty stanzas for every day of a month; 120 lines, ten for every month; and 365 words for every day of the year. ${ }^{36}$

The topic of De mundi transitu is the transience of earthly delights. Its first twelve lines establish that the world is fleeting and that death is inevitable. In the following seven stanzas, Columbanus muses on the futility of gaining wealth rather than bestowing it upon Christ. Next, in the eleventh stanza of the poem, he admonishes an unidentified reader to abandon this practice:

\section{Cogitare conuenit}

Te haec cuncta, amice

Absit tibi amare

Huius formulam uitae. ${ }^{37}$

In the following sixteen lines, Columbanus compares human beauty to sun-scorched grass, concluding that Christ's face is to be loved more than "flos carnis fragilis" (line 6o; the fragile flower of flesh). The seven following

33 David Howlett, "Two Works of Saint Columban," Mittellateinisches Jahrbuch 28.1 (1993), pp. $45^{-46 .}$

34 Discussed in Schaller, "De mundi transitu," pp. 249-51, who concludes that the added attribution was based on an earlier tradition.

35 For an overview of features of early Hiberno-Latin poetry, see David Howlett, "Early Insular Latin Poetry," Peritia 17-18 (2003-2004), 72-82.

36 Howlett, "Two Works," pp. 35-46.

37 Columbanus, De mundi transitu, lines 41-44. "It is fitting that you think of all these things, my friend; far be it from you to love the pattern of this life." 
stanzas list dangers that are to be avoided, including "[f]eminarum species / [p] er quas mors ingreditur" (lines 62-63; the forms of women, through whom death enters), "[p]oculum impiisimae" (line 69; the cup of a most unrighteous) and "uiam mortalium / [q]ua multis euenisse / [c] onspicis naufragium" (lines 82-84; the road of mortals, on which you [look] for many [a] shipwreck has occurred). In the last eight stanzas of the poem, Columbanus exhorts the reader to lift their heart's eyes from earthly things and focus on the joys of heaven.

Thus far, scholarship has only identified the Bible as one of Columbanus's sources. ${ }^{38}$ His description of sun-scorched grass, for instance, is clearly based on the Vulgate versions of Isaiah 40:6 and James 1:10-11 (correspondences marked with italics):

Omnis en caro foenum

Flagrans, licet florida

Sicque quasiflos foeni

Omnis eius est gloria;

\section{Orto sole arescit}

Foenum et flos deperit;

Sic est omnis iuventus,

Virtus cum defecerit. ${ }^{39}$

In addition to the Bible, Columbanus also appears to have made use of the late fifth-century text commonly referred to as Pseudo-Basil's De admonitio ad filium spiritualem (Admonition to a Spiritual Son). This short spiritual text was once attributed to Basil of Caesarea, but is now believed to be a work by Abbot

38 In addition, Walker, Sancti Columbani Opera, p. lvi, claims there are reminiscences of Ovid and Ausonius in this poem, but Smit, Studies, pp. 217-18, has demonstrated that the similarities that Walker points out are rather commonplace expressions.

39 Columbanus, De mundi transitu, lines $45^{-52}$. "Lo, all flesh is grass, burning though green, and like as the flower of grass is all its glory; At sunrise is scorched the grass, and the flower fades; so is all youth when manhood has failed." The relevant Vulgate texts, with the Douay-Rheims translation, are: "omnis caro faenum et omnis gloria eius quasi flos agri" (Isa. 40:6; All flesh is grass, and all the glory thereof as the flower of the field) and "dives autem in humilitate sua quoniam sicut flos faeni transibit. exortus est enim sol cum ardore et arefecit faenum et flos eius decidit et decor vultus eius deperiit ita et dives in itineribus suis marcescet" (James 1:10-11; And the rich, in his being low: because as the flower of the grass shall he pass away. For the sun rose with a burning heat and parched the grass: and the flower thereof fell off, and the beauty of the shape thereof perished. So also shall the rich man fade away in his ways). 
Porcarius of Lérins, written about the year 500 AD. ${ }^{40}$ The eighth chapter of $D e$ admonitio, headed "De saeculi amore fugiendo" (Concerning Fleeing the Love of This World), includes ideas and images that are similar to lines 40-84 of De mundi transitu. The opening lines of Pseudo-Basil's chapter, for instance, compare worldly beauty to withered hay that is struck by summer's heat, an image that is not unlike Columbanus's scorched grass. Next, both texts extend the simile to the youthful body. According to Columbanus, "[p]ulchritudo hominum / [s]enescens delabitur. / Omnis décor pristinus / [c]um dolor raditur" (lines 53-56; the beauty of men shall vanish in old age; all former comeliness is wiped away with grief), while De admonitio holds "Succedente enim senectute omnis décor pristinus iuventutis floridae deperit et quos in amorem sui antea concitabat [...] et quando mors venerit, tunc penitus omnis pulchritudo delebitur" (With the advent of old age, every pure beauty of florid youth is destroyed and what you loved before, you now find hateful, and when death comes, then all beauty will be totally destroyed). ${ }^{41}$ Like De mundi transitu, which notes that Christ's face is to be loved before all things, De admonitio spurs the reader to "[r] eflecte igitur ab his obscenis amoribus animum tuum et omnem amorem converte ad splendidissimam pulchritudinem Christi" (turn away therefore your soul from obscene loves and turn your love to the most splendid beauty of Christ). ${ }^{42}$ In both texts, the exhortation to love Christ's beauty is followed by a series of dangers to be avoided, including the fatal beauty of women, cups that should not be drunk from and nets that should not be stepped on. In addition to the enumerations of similar ideas, the two texts also have various phrases in common, as the following parallel passages demonstrate:

40 See James F. LePree, “Two Recently-Discovered Passages of the Pseudo-Basil's Admonition to a Spiritual Son (De admonitio ad filium spiritualem) in Smaragdus's Commentary on the Rule of St. Benedict (Expositio in regulam s. Benedicti) and the Letters (Epistolae) of Alcuin," Heroic Age 11 (2008). Available at http://www.heroicage.org/issues/11/lepree.php. Accessed 2018 August 31. I follow LePree and standing tradition in referring to the author of this text as "Pseudo-Basil."

41 Pseudo-Basil, De admonitio ad filium spiritualem, ed. Paul Lehmann, Erforschung des Mittelalters. Band V (Stuttgart, 1962), lines 224-26, p. 229; trans. J. F. LePree, "Pseudo-Basil's De admonitio ad filium spiritualem: A New English Translation," Heroic Age 13 (2010). Available at https://www.heroicage.org/issues/13/lepree2.php. Accessed 2018 August 31. Note the correspondence in phrasing between the two texts: "[p]ulchritudo [...] delabitur. Omnis decor pristinus [...]" (Columbanus) and "[...] omnis decor pristinus [...] pulchritudo delebitur" (Pseudo-Basil).

Pseudo-Basil, De admonitio ad filium spiritualem, ed. Lehmann, lines $236-38$, p. 23 o; trans. LePree, "Pseudo-Basil's De admonitio." 
Columbanus, De mundi transitu, lines $81-88$

Noli pronus pergere

Per uiam mortalium

Qua multi euenisse

Conspicis naufragium.

\section{Pseudo-Basil, De admonitio}

Perge iter laqueos

Cum suspensis pedibus

Per quos captos ceteros

Incautos conperimus. ${ }^{43}$

A last similarity between De mundi transitu and De admonitio is that both admonish a young person, addressed with "Caue ergo, fili" by Pseudo-Basil and with "Caueto filiole" by Columbanus. ${ }^{45}$ If Columbanus indeed drew inspiration from De admonitio, this would constitute the earliest known use of this influential early medieval text. ${ }^{46}$

De mundi transitu's only full manuscript witness is a ninth-century manuscript that once belonged to the monastery of St Gall: Zurich, Stadtbibliothek, C 78 (451), fols. 159r-6ov. The text was first published in 1604 AD by Melchior Goldast, who collated the Zurich manuscript with another manuscript from St Gall, which has since been lost. ${ }^{47}$ Both manuscripts appear to have been affected by some measure of scribal corruption. ${ }^{48}$ The most dramatic consequence of the poem's faulty transmission is the loss of line 106. Instead of providing a full seven-syllable line here, eye-skip has led a scribe to repeat a part of line 102, instead..$^{49}$ As a result, extant editions of the poem either leave line 106 empty or fill in a heptasyllabic line of their own. ${ }^{50}$

43 "Do not plunge headlong by the road of mortals, on which you [look] for many [a] shipwreck has occurred. Step between the nets with hesitant feet, for by those nets the rest we see were caught unawares." Correspondences in phrasing are marked with italics.

Pseudo-Basil, De admonitio ad filium spiritualem, ed. Lehmann, lines 247-49, p. 23o; trans. LePree, "Pseudo-Basil's De admonitio": "Don't set foot on the journey where you have seen many others shipwrecked. Avoid the snares which you see have captured the rest."

Pseudo-Basil, De admonitio ad filium spiritualem, ed. Lehmann, line 245, p. 23o; Columbanus, De mundi transitu, line 61.

46 Cf. LePree, "Two Recently-Discovered Passages."

47 Melchior Goldast, Paraeneticorum Veterum, pars I (Lindau, 16o4), p. 153.

48 Schaller, "De mundi transitu," p. 242.

49 Schaller, "De mundi transitu," p. 244, n. 28.

50 Walker leaves line 106 blank; Howlett, "Two Works," pp. 35-36, emends line 106 with "Melos decantata est" (a song is sung right through); Schaller, "De mundi transitu," p. 244, 
A new critical edition of De mundi transitu seems necessary in the light of a hitherto overlooked quotation of the poem that allows for the reconstruction of line 106. This quotation is found in Sedulius Scottus's Collectaneum miscellaneum, a ninth-century florilegium of mostly biblical and patristic sources. In section XVIII "De die iudicii" (Concerning Doomsday), presented as prose and misleadingly attributed to Saint Augustine of Hippo, are six stanzas (lines 93-96 and 101-120) from Columbanus's De mundi transitu (here indicated in italics):

AVGVSTinvs: Tunc dicetur morti ubi est contentio tua, et non erit, et item dicetur ubi est, mors, aculeus tuus, et nusquam erit. Regnabimus igitur cum Domino nostro Iesu Christo in illa beata familia quae in astris habitat: ubi senex non gemit, neque infans uagitat; ubi cibo superno plebs caelestis pascitur; ubi nemo moritur quod nemo nascitur; ubi aula regia regis summi sita est, in qua male resonans nulla uox audita est; ubi uita uiridis uera que futura est, quam nec mortis meroris meta consumptura est. Leti letantes acto letum regem uidebunt, cum regnante regnabunt, cum gaudente gaudebunt. Tunc dolor, tunc taedium, tunc labor delebitur. Tunc rex regum, rex mundus a mundis uidebitur. Ibi esse nostrum non habebit mortem, ibi nosse nostrum non habebit errorem, ibi amare nostrum non habebit offensionem. ${ }^{51}$

n. 28, opts for "canticis repleta est" (which is refilled with songs). The emendations by Howlett and Schaller both anticipate lines 107-8: "In qua male resonans / [n]ulla vox audita est" (in which resounding ill no voice is heard).

$5^{1}$ Sedulius Scottus, Collectaneum miscellaneum, сссм 67, ed. Dean Simpson (Turnhout, 1988), XVIII.29, lines 123-36. 'Then it is said to death 'where is your contention?', and it will not be, and again it is said, 'where, death, is your sting?', and it will not be anywhere. Therefore, we will reign with our Lord Jesus Christ with that blessed family which dwells among the stars: where the old does not groan, nor the infant cry; where on celestial food the heavenly folk are fed; where no one dies because no one is born; where the royal hall of the highest king is located, in which, resounding ill, no voice is heard; where life green and true shall be, which neither death nor [the fear of sorrow] shall destroy. Joyful after crossing death they shall see their joyful king, with Him reigning they shall reign, with Him rejoicing they shall rejoice. Then grief, then weariness, then toil shall be done away, then the King of kings, the pure King, shall be seen by the pure. There our being will not have death, there our knowing will have no fault, there our loving will have no misfortune." For the translation of the italicized lines that correspond with Columbanus's De mundi transitu, I have used Walker's translation. 
The attribution of this entire passage to Augustine is based on the fact that the material that surrounds the quotation from Columbanus, though not the quotation itself, indeed comes from works of Augustine. ${ }^{52}$

The discovery of this quotation is significant. For one, the text in Scottus's Collectaneum provides a number of alternative readings, such as "beata familia quae in astris habitat" (blessed family which dwells among the stars) for the Zurich manuscript's "beata familia, quae in altis habitat" (blessed family which dwells on high) (lines 93-94). More crucially, Scottus appears to have preserved the lost line 106 of De mundi transitu:

\section{Columbanus, De mundi transitu, Sedulius Scottus, Collectaneum \\ lines 101-12}

Ubi cibo superno

Plebs caelestis pascitur,

Ubi nemo moritur

Quia nemo nascitur,

Ubi aula regia

In qua male resonans

Nulla vox audita est,

Ubi vita viridis

Veraque futura est,

Quam nec mors nec meroris

Metus consumpturus est. ${ }^{53}$ ubi cibo superno

plebs caelestis pascitur;

ubi nemo moritur

quod nemo nascitur;

ubi aula regia

regis summi sita est, in qua male resonans

nulla uox audita est;

ubi uita uiridis

uera que futura est, quam nec mortis meroris meta consumptura est. ${ }^{54}$

$5^{2}$ The lines preceding the quotation from De munditransitu are from Augustine's Sermones; the lines following are from De ciuitate Dei. See F. Dolbeau, Supplement, ссм LXVII Supplementum (Turnhout, 1990), pp. 30-31. Notably, at least one other quotation of Columbanus, from his Instructiones, in Scottus's Collectaneum is similarly introduced by a quotation from Augustine and, hence, attributed to "Avgvstinvs," Scottus, Collectaneum, ed. Simpson, XVI.16-24. Another citation from the Instructiones is attributed to "FAVsTVs," Scottus, Collectaneum, ed. Simpson, XvII.7. The identification of sources was added in the margins of the text by a scribe and may not be original. See Scottus, Collectaneum, ed. Simpson, $\mathrm{xi}, \mathrm{xxx}-\mathrm{xxxi}$.

53 "Where on celestial food the heavenly folk are fed; where no one dies because no one is born; where the royal hall ..., in which resounding ill no voice is heard; where life green and true shall be, which neither death nor [the fear of sorrow] shall destroy."

54 Scottus, Collectaneum ed. Simpson, XVIII.29, lines 127-31. 
The line "regis summi sita est" in Scottus's Collectaneum may well have been part of Columbanus's original poem: it has seven syllables and a trisyllabic rhyme with line 108 "Nulla vox audita est." ${ }^{55}$ Moreover, the reconstructed lines "ubi aula regia / regis summi sita est" (lines 105-6; where the royal hall of the highest king is located) more or less correspond to the Old English phrase "ac pær is bæs hestæn kynges kynerice" (line 9o; but there is the kingdom of the highest king) in Irvine VII, which also uses passages of De mundi transitu that were not copied in Scottus's Collectaneum. In other words, Scottus's Collectaneum and Irvine VII, as two independent witnesses, allow for the reconstruction of the missing line of Columbanus's De mundi transitu. As a result, this poem by one of Ireland's earliest Latin poets is once again complete.

\section{Columbanus's De mundi transitu as a Source of Irvine Homily vII}

Finding sources has long been a valued method when it comes to studying Old English homilies. The identification of a source provides information that may be used to establish matters of textual criticism and to gain an insight into the methods of homilists, and it allows for the reconstruction of the intellectual milieu in which these homilists operated. ${ }^{56}$ After establishing the parameters for identifying Columbanus's De munditransitu as a source for Irvine VII, the remainder of this paper features an analysis of the corresponding passages.

In order to identify a source conclusively, relative chronology needs to be considered, as well as the question of whether the source could have been available to the borrower. For the use of Columbanus's De mundi transitu in Irvine VII, the relative dates of the two texts are unproblematic: the proposed late sixth-century Latin source certainly predates the Old English homily in Bodley 343, which may have been based on a tenth-century exemplar. While no Anglo-Saxon manuscripts of De mundi transitu survive, the poem may have become available in England via the monastery of St Gall. This monastery had

55 An alternative explanation, that Scottus copied a version of the text that is similar to the one preserved in the Zurich manuscript, noticed the error and supplied the missing line himself is less likely, since such emendations are not strictly necessary in a collection that probably functioned as a notebook. Cf. Scottus, Collectaneum, ed. Simpson, xxii.

$5^{6}$ For appraisals of source study, in particular with relation to homilies, see James E. Cross, "The Literate Anglo-Saxon-On Sources and Disseminations," PBA 58 (1972), 67-100; D. G. Scragg, "Source Study," in Reading Old English Texts, ed. Katherine O'Brien O'Keeffe (Cambridge, 1997), pp. 39-58; Charles D. Wright, "Old English Homilies and Latin Sources," in The Old English Homily, ed. Kleist, pp. 15-66. On the potential pitfalls of source study, see Pelle's essay above, p. 214. 
close ties to early medieval England and its library contained at least two manuscripts of the poem. ${ }^{57} \mathrm{~A}$ third prerequisite for the identification of a source is the exclusion of coincidental similarity. ${ }^{58}$ In the case of Irvine VII and Columbanus's De mundi transitu, the sheer number of correspondences, both in terms of ideas and phrasing, is so substantial that the similarity is unlikely to have arisen without the Old English homilist having read the Hiberno-Latin poem, either directly or indirectly. ${ }^{59}$

Since both the first half of Irvine viI and most of Columbanus's De mundi transitu survive only in single manuscripts, scribal corruption may have gone unnoticed. As such, a comparison between corresponding passages of the two texts may give cause for emendation. The four opening lines of De mundi transitu and its Old English adaptation are a case in point:

\section{Columbanus, De munditransitu, Irvine VII, lines 65-69 lines 1-4}

Mundus iste transibit,

Cottidie decrescit;

Nemo vivens manebit,

Nullus vivus remansit. ${ }^{60}$
For pam pe we iseoð pis læne lif mid fræcednesse and mid mycele earfoðnesse ifulled, and ylce dæ3 pis lif wonæð and wursæð; and na lifiende mon ne purhwune(ð) on pisse weorlde, ne nan eft to lafe ne wurð. 61

Without knowledge of the Latin source, Irvine has suggested that the problematic phrase "ne nan eft to lafe ne wurð" in Irvine vir could be corrected by changing "lafe" into "life," ${ }^{2}$ rendering the translation 'and no one becomes

57 For the ties to early medieval England, see, e.g., J. M. Clark, The Abbey of St Gall as a Centre of Literature \& Art (Cambridge, 1926), pp. 55-69.

58 Scragg, "Source Study," p. 41.

59 There is, of course, always the possibility of an intermediary source, such as a florilegium. Cf. Wright, "Old English Homilies and Latin Sources," p. 17. Part of Columbanus's De mundi transitu circulated in the ninth-century florilegium Collectaneum miscellaneum by Sedulius Scottus, as established above.

6o "This world shall pass, daily it declines; none shall remain living, no one has remained alive."

61 "Because we see this transitory life filled with danger and with great difficulty, and every day this life wanes and grows worse; and no living man remains in this world, nor does anyone become what is left[?] afterwards." 
alive again' - what is dead stays dead. The emendation of "to lafe" to "to life" seems supported by the Latin "vivus" (alive) in "Nullus vivus remansit." ${ }^{63}$

Irvine vir's rendition of the next four lines of De mundi transitu are suggestive of scribal corruption in the Latin text:

\section{Columbanus, De munditransitu, lines $5^{-8}$}

\section{Totum humanum genus}

Ortu utitur pari,

Et de simili vita

Fine cadit aequali ${ }^{64}$

\section{Irvine VII, lines 69-70}

The sense of the Old English text here appears superior to that of the Latin: every human starts and ends life in the same manner, even though they lead different lives. The Latin poem's notion that the whole human race leads a "simili vita" (a similar life) strikes as odd. Perhaps "de simili" is a scribal corruption of the ablative form of dissimilis (unlike, dissimilar), "dissimili." Alternatively, the Old English homilist caught on to the unlikely notion that all people lead similar lives and decided to correct the sense of the Latin source.

The next four lines in Columbanus's De munditransitu, which outline the inevitability of death, correspond with the Old English in overall sense and phrasing:

\section{Columbanus, De mundi transitu, ～Irvine VII, lines 70-72 lines 9-12}

Differentibus vitam

Mors incerta subripit,

Omnes superbos vagos

Meror mortis corripit. ${ }^{66}$

\begin{abstract}
Ne nan swa longe her on weorlde ne leofæð, pæt eft pe deap hine ne zenime, and pa modizæn and pa oferhudizen deapes gneornung grip ${ }^{67}$
\end{abstract}

63 Arguably, the clause "ne nan eft to lafe ne wurð" could be translated as something like "nor will one become as a remnant afterwards, i.e. nor will anyone remain after"; in which case there is no need to explain "lafe" as an error for "life," since the implication would be that there will be no surviving living persons. I owe this suggestion to the anonymous reviewer.

64 "The whole human race uses a like origin, and after a common life falls by an equal ending."

65 "All mankind is born alike into this world, although their life will be unlike afterwards; and again they all depart in the end."

66 "For those who postpone life death creeps on unsure, all the proud wanderers sorrow of death seizes."

67 "No one lives so long here on the world that death does not take him then, and the grief of death grabs the proud ones and the overconfident ones." 
With respect to Schabram's analysis of the words for pride in Irvine VII, it is interesting to note that the tautological word pair "pa modizæn and pa oferhudizen" here renders a single Latin phrase "superbos vagos." As such, it is indeed possible that the West Saxon "modizæn" was added to clarify the Anglian "oferhudizen" in the course of this text's transmission, as Schabram has suggested. ${ }^{68}$

The next two stanzas of Columbanus's De mundi transitu deal with the impermanence of earthly possessions. The Old English follows the Latin closely:

\section{Columbanus, De mundi transitu, Irvine viI, lines 72-77 lines $13^{-20}$}

Quod pro Christo largiri

Nolunt, omnes avari

Inportune amittunt;

Post se colligunt alii.

Parvum ipsi viventes

Deo dare vix audent;

Morti cuncta relinquunt,

Nihil de ipsis habent. ${ }^{69}$
And pæt heo her for Godes lufe syllen nolden heoræ sawle to hælpe, heo hit rædlice forlæteð, and oðre perto foð, pa heo for Criste hit letæn nolden, pa hwile pe heo lifedon. Ac penne pe deap cymæð, penne sceolen heo forlæten heoræ æhtæ heoræ unðancæs, and heo his penne nan ping nabbæð. ${ }^{70}$

The sentence structure in the Old English is somewhat obscure and Irvine explains that " $[\mathrm{t}]$ he direct object of syllen (73) is pret (72) meaning 'that which'. This is picked up by the pronoun hit in 73 and 74 , and by the partitive genitive his in 76 . Its meaning is made explicit in heorce cehtce (76)." ${ }^{71}$ Irvine's interpretation of the Old English is confirmed by the Latin source text; in fact, the Old English word order "pæt heo her for Godes lufe syllen nolden" may well show the influence of Latin "quod pro Christo largiri nolunt."

68 Cf. Schabram, Superbia, pp. 83-84.

69 "What to bestow for Christ they will not, all misers lose out of season; after them others gather. Living but little themselves, they scarce venture to give to God; to death they leave their all, they keep nothing of themselves."

70 "And that which they did not want to give here for God's love to help their soul, they shall leave it soon, and others succeed thereto, since they did not want to give it up for Christ, during the time that they lived. But when death comes, they must leave their possessions against their will, and they will then have nothing of this."

71 Irvine, p. 203; Irvine's explanation of the structure of this sentence is likely a reaction to Belfour's incorrect insertion of a direct object "(their life)" in the translation of this passage: "And because they here would not give (their life) for the love of God to help their soul they shall soon lose it, and the others shall obtain it, since they would not give it up for Christ's sake while they were living." (cf. Belfour, p. 129). 
The next stanza of Columbanus's poem is translated almost ad litteram in the Old English homily:

\section{Columbanus, De mundi transitu, $\quad$ Irvine viI, lines $77-78$ \\ lines 21-24}

Cottidie decrescit

Vita praesens quam amant;

Indeficiens manebit

Sibi poena quam parant. ${ }^{72}$
Ylce dæ3 pis andwearde lif wonæð pe we lufiæð, ac pa pine ne woniæð pam monnum pe heom nu æfter earniæd. ${ }^{73}$

The word "pine" in the Old English text merits a comment here. The first instances of the word pin meaning "pain, torment" in English are all found in twelfth-century manuscripts; as such, Irvine has suggested that the word, which is used three times in this homily (ll. 55, 77, 157) probably represents a Middle English gloss to the Old English wite "pain, torment."74 While this is possible, it is noteworthy that the use of the word "pine" in this passage may reflect the Latin "poena," which is also the origin of the word in English. If so, the history of the word may stretch back to the pre-Ælfrician Anglian original of this part of the homily in Bodley 343 .

Lines 25-40 of De mundi transitu, which outline how sinners are unaware of the torments being prepared for them in hell, are not included in Irvine viI. Since the composer of this composite homily had expanded on the horrors of hell in the section preceding the rendition of Columbanus's poem, the lines may have been considered too repetitive.

Instead, the homily moves on to a reflection on the frailty of the human body, again following Columbanus in comparing the human body to a plant withered in the sun's heat:

72 "Daily declines the present life they love; unfailing remains the penalty they prepare for themselves."

73 "Every day this present life which we love diminishes, but the torments do not diminish for the people who are now earning them for afterwards."

74 Irvine, p. 203. 


\section{Columbanus, De mundi transitu, lines 41-56}

\section{Cogitare convenit}

Te haec cuncta, amice.

Absit tibi amare

Huius formulam vitae.

Omnis en caro foenum

Flagrans, licet florida,

Sicque quasi flos foeni

Omnis eius est gloria;

Orto sole arescit

Foenum et flos deperit;

Sic est omnis iuventus,

Virtus cum defecerit.

Pulchritudo hominum

Senescens delabitur.

Omnis decor pristinus

cum dolore raditur. ${ }^{75}$
Irvine VII, lines $79^{-83}$

Uton we penne, leofe men, pas ping alle zemunen and ipencean pæt pæt mennisce lichame is swa blowende wurten, pe for pare sunnæ hæte fordruziæð and forscrincæð. Swa eac bæs monnes zеozepæ and fegernes dæb. Penne peo ælde on him sizæð mid unhæle, all pare зеозеðе fezernes awe 3 awit and forwurð. ${ }^{76}$

The Old English is an abbreviation of the Latin in that the images of grass and flowers are replaced by the simple "blowende wurten" (blooming plants). Irvine found a close analogue to this passage in Blickling $\mathrm{v}$ :

We witon pæt Crist sylfa cwæb purh his sylfes mup, "ponne ge geseop growende \& blowende ealle eorpan wæstmas, \& pa swetan stencas gestincað para wudu-wyrta, pa sona eft adrugiap \& forpgewitap for pæs sumores hæton'. Swa ponne gelice bið pære menniscan gecynde pæs

75 "It is fitting that you think of all these things, my friend. Far be it from you to love the pattern of this life. Lo, all flesh is grass, burning though green, and like as the flower of grass is all its glory; At sunrise is scorched the grass, and the flower fades; so is all youth when manhood has failed. The beauty of men shall vanish in old age. All former comeliness is wiped away with grief."

76 "Let us then, dear men, remember all these things and consider that the human body is like blossoming plants, which dry up and wither because of the sun's heat. So, too, do a person's youth and fairness. When old age seizes on him with ill health, all fairness of youth goes away and withers." 
lichoman ponne se geogophad ærest blowep \& fægerost bið, he ponne rape se wlite eft gewitep \& to ylde gecyrrep, \& he ponne sibpon mid sare geswenced bið, mid mislicum ecum \& tyddernessum. \& eal se lichoma geunlustap pa geogoðlustas to fremmenne pa pe he ær hatheortlice lufode, \& him swete wæron to aræfnenne. ${ }^{77}$

The Blickling homilist's comparison of the elderly body in decline to blooming plants withering away in the heat is indeed similar to the image used in Irvine VII. However, as I have discussed elsewhere, ${ }^{78}$ Blickling v here draws on Pseudo-Basil's De admonitio ad filium spiritualem, the same source used by Columbanus.

The next passages in Columbanus's poem and Irvine VII urge the audience to love Christ's countenance rather than the frail youthful state of the body:

\section{Columbanus, De mundi transitu, $\quad$ Irvine VII, lines 83-85 lines $57-60$}

\section{Vultus Christi radius \\ Prae cunctis amabilis \\ Magis diligendus est \\ Quam flos carnis fragilis. ${ }^{79}$}

Ac Cristes ansyne is to lufizenne ofer alle oðer ping mucele swiðor penne pes lichames зеозæðhad. ${ }^{80}$

As established above, this exhortation to love Christ's beauty above all else ultimately derives from Pseudo-Basil's De admonitio.

The next seven stanzas of Columbanus's poem, which warn the reader about the dangers of women, drinking and lust, are not incorporated in the Old English homily. Since these stanzas feature a rather negative depiction of women, the omission may indicate that this homily catered to a mixed, lay audience. Indeed, if this homily was intended for Rogationtide, as has been

$77 \quad B H$, pp. 57-59. "We know that Christ himself said, through his own mouth: 'When you see all the earth's fruits growing and blooming, and smell the sweet odours of the plants, then immediately afterwards they shall dry up and wither away because of the summer's heat.' So, it (the fruit) is like the nature of a man's body, when youth first blooms and is fairest, then quickly beauty fades and turns to old age, and afterwards he is troubled by pain and by various ailments and infirmities. And the whole body loathes to perform those youthful lusts that he loved so earnestly before, and which were sweet to him to perform." Cf. Irvine, p. 191.

78 Porck, Old Age in Early Medieval England, pp. 95-97.

79 "The radiance of Christ's face, lovely before all things, is more to be desired than the frail flower of flesh."

8o "But Christ's countenance is to be loved over all other things, much more than the youth of the body." 
suggested, the homily would likely address a wide audience, consisting of both men and women. ${ }^{81}$

When the Old English homily takes up Columbanus's De mundi transitu again, it is to remind the audience to focus on heaven:

\section{Columbanus, De mundi transitu, lines 89-104 \\ Irvine VII, lines $85^{-9}$ o}

De terrenis eleva

Tui cordis oculos;

Ama amantissimos

Angelorum populos;

Beata familia,

Quae in altis habitat,

Ubi senex non gemat,

Neque infans vagiat

Ubi laudis Domini

Nulla vox retinetur,

Ubi non esuritur,

Ubi numquam sititur,

Ubi cibo superno

Plebs caelestis pascitur,

Ubi nemo moritur

Quia nemo nascitur ${ }^{82}$
Ac habbæp eowre heorte on pisse eorplice zewinne and earniæp eow pæt heofenlice rice, pær is ece eadiznesse: pær eald ne graneð, ne child ne scræmeð. Ne bið pær purst, ne hungor, ne wop, ne teoðe zegrind, ne morper, ne man, ne pær nan ne swæltæð, for bam ðe pær ne byð nan acenned; ne per ne byð sar, ne seore ææ, ne nan longing, ne unlustes zewin. ${ }^{83}$

81 Blickling $\mathrm{x}$, a homily associated with Rogationtide, addresses its audience as "ge weras ge wif, ge geonge ge ealde, ge snotre ge unwise, ge pa welegan ge pa pearfan" (men or women, young or old, wise or unwise, wealthy or poor), see Milton McC. Gatch, "The Unknowable Audience of the Blickling Homilies," ASE 18 (1989), 108-10. On the mixed audience of vernacular Rogationtide homilies, see also Johanna Kramer, Between Earth and Heaven: Liminality and the Ascension of Christ in Anglo-Saxon Literature, Manchester Medieval Literature and Culture (Manchester, 2014), p. 187, n. 3.

82 "From earthly things lift up your heart's eyes; love the most loving hosts of angels; blessed family which dwells on high, where the old does not groan nor the infant cry, where of God's praise no voice is restrained, where there is no hunger, where there is never thirst, where on celestial food the heavenly folk are fed, where none dies because none is born."

83 "But have? your heart on this earthly labour and earn for yourself that heavenly kingdom; there is eternal happiness: there the old does not groan, nor does the child scream. Nor is there thirst, or hunger, or weeping, or grinding of teeth, or murder, or evil, one does not 
Comparison with the Latin source makes clear that the Old English "habbæp" (have) is likely a corrupted form of "hebbæp" (lift) — the audience is asked to lift their heart from earthly matters so as to gain the heavenly kingdom. The Old English homily has retained a number of Columbanus's unique celestial features, such as "Ubi senex non gemat, / Neque infans vagiat" (lines 95-96; cf. "pær eald ne graneð, ne child ne scræmeð”) and “Ubi nemo moritur / Quia nemo nascitur" (lines 103-4; cf. "ne pær nan ne swæltæð, for pam ðe pær ne byð nan acenned"). These idiosyncratic features are supplemented by more commonplace descriptions of the joys of heaven, such as the presence of eternal happiness, and the absence of weeping, grinding of teeth, murder, evil, pain and sorrow. Hildegard Tristram has shown that such enumerations of celestial joys, in both positive and negative form, are frequently found in Old English homilies. ${ }^{84}$ Blickling viI features a typical example of the pattern that shows some similarity to the description of heaven in Irvine VII:

Pær bip a ece gefea buton unrotnesse, \& geogop buton yldo. Ne bip pær sar ne gewinn, ne nænig unepnes, ne sorg ne wop, ne hungor, ne purst, ne ece yfel. Ne pær mon his feond findeð, ne his freond forlætep. ${ }^{85}$

As such, whilst incorporating Columbanus's idiosyncratic De mundi transitu into Irvine VII, the homilist occasionally fell back on homiletic clichés.

A similar strategy was followed in the adaptation of the last lines of Columbanus's poem, which describe the rejoicing of the faithful when they are allowed to see God in heaven. The Old English follows the sense of these last stanzas, but in an abbreviated form:

die there because no one is born there; there is no pain, or sorrow, or longing or conflict of evil desire."

84 Hildegard L. C. Tristram, "Stock Descriptions of Heaven and Hell in Old English Prose and Poetry," NM 79 (1978), 102-13.

$85 B H$, pp. 103-5. "There is eternal joy without sadness and youth without old age. There is no grief or labour, or any uneasiness, or sorrow, or weeping, or hunger, or thirst, or eternal evil. There no man finds his enemy or abandons his friend." 
Columbanus, De mundi transitu, lines $105^{-16}$

Ubi aula regia

[regis summi sita est]

In qua male resonans

Nulla vox audita est,

Ubi vita viridis

Veraque futura est,

Quam nec mors nec meroris

Metus consumpturus est.

Laeti leto transacto

Laetum regem videbunt;

Cum regnante regnabunt,

Cum gaudente gaudebunt. ${ }^{87}$
Irvine VII, lines 9o-93

Ac pær is pæs hestæn kynges kynerice, and pær wuniæp alle pa be Godes bodu heolden on ece murhðe; and heo dæ3hwamlice pene heofenlice kyng bliðne iseoð, and heo mid him and mid his halzan libbæp, and rixæð a on eccenesse. ${ }^{86}$

Some details of De mundi transitu are retained in the Old English text, such as the notion that the dead will see a joyful king in heaven. In addition, as noted above, the Old English phrase "[a]c bær is pæs hestæn kynges kynerice" corresponds to lines 105-6 of De mundi transitu, as reconstructed on the basis of Scottus Sedulius's Collectaneum miscellaneum. The homilist of Irvine VII has not only abbreviated this part of the source text, but also combined it with a typical closing formula. Similar formulas are found throughout the Old English homiletic corpus, including another anonymous homily in Bodley 343, Irvine $\mathrm{v}$, which ends with an exhortation to aid God, "be ðe leofæð and rixæð a a on ecenesse. AMEN" (who lives and rules forever in eternity. Amen). ${ }^{88}$

86 "But there is the kingdom of the highest king, and there dwell all those who observed God's commandments in eternal happiness; and they will daily see the joyous heavenly king, and they will live with him and with his saints, and they will reign forever in eternity."

87 "Where the royal hall (of the highest king is situated), in which resounding ill no voice is heard, where life green and true shall be, which neither death nor [the fear of sorrow] shall destroy. Joyful after crossing death they shall see their joyful king; with him reigning they shall reign, with him rejoicing they shall rejoice."

Irvine, p. 143, lines 189-9o. 


\section{Conclusion}

In composing an Old English homily on the fleeting nature of earthly joys, an anonymous homilist turned to the Hiberno-Latin poem De mundi transitu. This homilist clearly understood the poem's contents and recognized its relevance for the theme of his homily. While his adaptation stays close to the sense of his source, nothing of Columbanus's highly complex form and structure appears to have been retained in the Old English text. Instead, the poem has been transformed into relatively unembellished prose and occasionally mixed with homiletic commonplaces.

In a foundational article on source criticism, Charles Wright described the research into the sources of Old English homilies as ultimately "unfinished business." 89 Indeed, the identification of Columbanus's De mundi transitu as a source for an anonymous Old English composite homily in Bodley 343 raises more questions than have been answered in this paper. Aside from the matters of textual criticism dealt with above, scholars may wish to investigate the exact manner of how the Latin poem was transposed into Old English and how the treatment of this source compares to how this homily's other sources were transformed in the process of composition. For the study of the Hiberno-Latin source text, its use in an Old English homily also triggers various questions, such as how it became available in early medieval England and whether its manuscript transmission may be suggestive of earlier homiletic application. Moreover, in light of the poem's noted similarities to the Old English elegies, Columbanus's De mundi transitu as a potential analogue of these Old English poems may deserve more than a passing mention.

89 Wright, “Old English Homilies and Latin Sources," p. 6o. 